\title{
Front Matter: Volume 9345
}

, "Front Matter: Volume 9345," Proc. SPIE 9345, High Power Lasers for Fusion Research III, 934501 (16 April 2015); doi: 10.1117/12.2183972

SPIE. Event: SPIE LASE, 2015, San Francisco, California, United States 


\section{PROCEEDINGS OF SPIE}

\section{High Power Lasers for Fusion Research III}

Abdul A. S. Awwal

Monya A. Lane

Editors

10 and 12 February 2015

San Francisco, California, United States

Sponsored and Published by

SPIE 
The papers included in this volume were part of the technical conference cited on the cover and title page. Papers were selected and subject to review by the editors and conference program committee. Some conference presentations may not be available for publication. The papers published in these proceedings reflect the work and thoughts of the authors and are published herein as submitted. The publisher is not responsible for the validity of the information or for any outcomes resulting from reliance thereon.

Please use the following format to cite material from this book:

Author(s), "Title of Paper," in High Power Lasers for Fusion Research III, edited by Abdul A. S. Awwal, Monya A. Lane, Proceedings of SPIE Vol. 9345 (SPIE, Bellingham, WA, 2015) Article CID Number.

ISSN: 0277-786X

ISBN: 9781628414356

Published by

SPIE

P.O. Box 10, Bellingham, Washington 98227-0010 USA

Telephone +1 3606763290 (Pacific Time) · Fax +1 3606471445

SPIE.org

Copyright (@ 2015, Society of Photo-Optical Instrumentation Engineers.

Copying of material in this book for internal or personal use, or for the internal or personal use of specific clients, beyond the fair use provisions granted by the U.S. Copyright Law is authorized by SPIE subject to payment of copying fees. The Transactional Reporting Service base fee for this volume is $\$ 18.00$ per article (or portion thereof), which should be paid directly to the Copyright Clearance Center (CCC), 222 Rosewood Drive, Danvers, MA 01923. Payment may also be made electronically through CCC Online at copyright.com. Other copying for republication, resale, advertising or promotion, or any form of systematic or multiple reproduction of any material in this book is prohibited except with permission in writing from the publisher. The CCC fee code is 0277-786X/15/\$18.00.

Printed in the United States of America.

Publication of record for individual papers is online in the SPIE Digital Library.

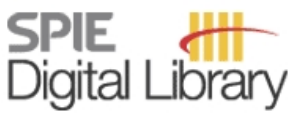

SPIEDigitalLibrary.org

Paper Numbering: Proceedings of SPIE follow an e-First publication model, with papers published first online and then in print. Papers are published as they are submitted and meet publication criteria. A unique citation identifier (CID) number is assigned to each article at the time of the first publication. Utilization of CIDs allows articles to be fully citable as soon as they are published online, and connects the same identifier to all online, print, and electronic versions of the publication. SPIE uses a six-digit CID article numbering system in which:

- The first four digits correspond to the SPIE volume number.

- The last two digits indicate publication order within the volume using a Base 36 numbering

system employing both numerals and letters. These two-number sets start with $00,01,02,03,04$, $05,06,07,08,09,0 A, 0 B \ldots$. OZ, followed by 10-1Z, 20-2Z, etc.

The CID Number appears on each page of the manuscript. The complete citation is used on the first page, and an abbreviated version on subsequent pages. 


\title{
Contents
}

\author{
$\checkmark \quad$ Authors \\ vii Conference Committee \\ ix Introduction
}

\section{SESSION 1 HIGH POWER LASER FACILITIES}

934503 The LMJ: overview of recent advancements and very first experiments [9345-1]

$934504 \quad$ High peak power diode stacks for high energy lasers [9345-2]

934506 Inertial fusion power plant concept of operations and maintenance [9345-4]

\section{SESSION 2 HIGH POWER OPTICAL MATERIALS}

934508 Laser damage resistance qualification of large optics for high power laser (Invited Paper) [9345-6]

934509 Optical damage performance measurements of multilayer dielectric gratings for high energy short pulse lasers [9345-8]

93450 A In-situ investigation of damage processes on fused silica induced by a pulsed $355 \mathrm{~nm}$ laser with high repetition rate [9345-9]

9345 OB Roughness reduction on aspheric surfaces [9345-27]

\section{SESSION 3 SIMULATIONS AND EXPERIMENTS}

9345 OC Dynamics of molecular clouds: observations, simulations, and NIF experiments (Invited Paper) [9345-10]

9345 OD Near field intensity trends of main laser alignment images in the National Ignition Facility (NIF) [9345-11]

9345 OE Laser performance operations model (LPOM): the computational system that automates the setup and performance analysis of the National Ignition Facility (Invited Paper) [9345-12]

9345 OF Advanced scheme for high-yield laser driven proton-boron fusion reaction [9345-13] 
$9345 \mathrm{OH} \quad$ The multiple-pulse driver line on the OMEGA laser [9345-15]

9345 Ol The commissioning of the advanced radiographic capability laser system: experimental and modeling results at the main laser output [9345-16]

$93450 \mathrm{~J} \quad$ Freeform beam shaping in optical systems of high-power lasers [9345-17]

POSTER SESSION

9345 OK COMBINE*: an integrated opto-mechanical tool for laser performance modeling [9345-18]

$9345 \mathrm{OL}$ Centroid stabilization in alignment of FOA corner cube: designing of a matched filter [9345-19]

9345 OM The virtual beamline (VBL) laser simulation code [9345-20]

9345 OP Impact of FM-AM conversion on smoothing by spectral dispersion [9345-23]

$93450 Q$ A robust in-situ warp-correction algorithm for VISAR streak camera data at the National Ignition Facility [9345-24]

9345 OR Diagnostics of pulse contrast for petawatt laser in SGII [9345-25] 


\title{
Authors
}

Numbers in the index correspond to the last two digits of the six-digit citation identifier (CID) article numbering system used in Proceedings of SPIE. The first four digits reflect the volume number. Base 36 numbering is employed for the last two digits and indicates the order of articles within the volume. Numbers start with 00, 01, 02, 03, 04, 05, 06, 07, 08, 09, OA, OB...0Z, followed by 10-1Z, 20-2Z, etc.

\author{
Alessi, D., 09 \\ Anklam, Tom, 06 \\ Arnold, P., Ol \\ Awwal, Abdul, OL \\ Barty, C. P. J., Ol \\ Baver, Marc, 04 \\ Bellutti, P., OF \\ Beltsar, llona, OD \\ Bertuccio, G., OF \\ Boley, C. D., Ol \\ Boucke, Konstantin, 04 \\ Bourgeade, Antoine, OP \\ Bowers, M. W., Ol \\ Britten, J. A., 09 \\ Budge, T. S., 01 \\ Burkhart, Scott, OD \\ Carr, C. W., 09 \\ Casner, Alexis, OC \\ Celliers, Peter M., OQ \\ Chambonneau, M., 08 \\ Chatagnier, Aurore, OP \\ Chen, Jian, OA \\ Christensen, K., Ol \\ Coïc, Hervé, OP \\ Courchinoux, R., 08 \\ Crane, J. K., Ol \\ Crivellari, M., OF \\ Cross, D. A., 09 \\ Dawson, J. W., Ol \\ d'Humières, Emmanuel, OP \\ Diaz, R., 08 \\ Di Nicola, J. M., Ol, OK, OM \\ Donaldson, W. R., OH \\ Dong, Jingtao, OA \\ Donval, T., 08 \\ Dorrer, C., $\mathrm{OH}$ \\ Duck, Richard, 04 \\ Dunne, Mike, 06 \\ Erbert, G., Ol \\ Fair, J. E., 09 \\ Feigenbaum, E., Ol, OM \\ Guss, G., 09, 01 \\ Hackel, R. P., 09 \\ Haefner, C., 09, 01 \\ Heebner, J. E., Ol \\ Heeter, Robert F., OC \\ Hermann, M. R., Ol \\ Hill, E. M., $\mathrm{OH}$ \\ Homoelle, D., 0 I
}

\author{
House, Ronald, $\mathrm{OE}$ \\ Jarboe, J. A., 0 l \\ Jiang, John, 04 \\ Kalantar, Daniel H., $O Q$ \\ Kane, Jave O., OC \\ Kasper, Jack, 06 \\ Kelly, J. H., $\mathrm{OH}$ \\ Kiontke, S., OB \\ Knutson, Brad, 06 \\ Kokot, Sebastian, OB \\ Korn, G., OF \\ KosC, T. Z., OH \\ Kraines, B. J., OM \\ Krasa, J., OF \\ Kucharik, M., OF \\ Labaria, George R., $\mathrm{OQ}$ \\ Lamaignère, L., 08 \\ Lang, Dwight, 06 \\ Laskin, Alexander, 0J \\ Laskin, Vadim, OJ \\ Lawson, J. K., Ol \\ Leach, Richard R., Jr., OD, OL \\ Learn, R. J., OM \\ Leblanc, Adrien, OP \\ Liu, Daizhong, OR \\ Loiseau, Pascal, OP \\ Lowe-Webb, Roger, OD, Ol, OL \\ Luke, K. J., OM \\ Luthi, R., 09 \\ Malinowska, A., OF \\ Mancini, Roberto C., OC \\ Mangione, A., OF \\ Margarone, D., OF \\ Martinez, David A., OC \\ Mau, Derek, 06 \\ McCandless, K. P., Ol, OM \\ McHale, B., Ol \\ Miller Kamm, Victoria, OD, OL \\ Mite, Roberto, 04 \\ Morrissey, M., OF \\ Negoita, Viorel C., 04 \\ Negres, R. A., 09 \\ Ngo, Tony, OL \\ Nicolaizeau, M., 03 \\ Nissen, J. D., 09 \\ Ostrun, Aleksei, oJ \\ Ouyang, Xiaoping, OR \\ Pelz, L. J., Ol \\ Penninckx, Denis, OP
}


Pham, P.P., Ol

Picciotto, A., OF

Pound, Mare W., OC

Prantil, M. A., Ol

Rehak, M. L., OI, OK

Rever, M. A., Ol

Riedel, W., OM

Roberts, Randy, OL

Roberts, Valerie, 06

Roff, Robert, 04

Rushford, M. C., Ol

Sacks, R. A., Ol, OM

Salmon, Thad, OD

Shaw, Michael, OE, Ol

Sheehan, Timothy, 06

Shi, Y., OF

Shih, Ming, 04

Smauley, D., 0

Smith, L. K., O

Speck, R., Ol

Spinka, T. M., ol

Stanion, K. A., 09

Szydlowsky, A., OF

Tietbohl, G., ol

Treusch, Georg, 04

Ullschmied, J., OF

Velyhan, A., OF

Vethake, Thilo, 04

Vivini, P., 03

Warrick, Abbie L., $\mathrm{OQ}$

Waxer, L. J., $\mathrm{OH}$

Wegner, P. J., Ol

Widmayer, C., Ol

Wilhelmsen, Karl, OD, OL

Wu, Zhouling, OA

Yang, S. T., Ol

Zhu, Baoqiang, OR

Zhu, Jian, OR

Zhu, Jianqiang, OR 


\title{
Conference Committee
}

\author{
Symposium Chairs
}

Guido Hennig, Daetwyler Graphics AG (Swtizerland)

Yongfeng Lu, University of Nebraska-Lincoln (United States)

Symposium Co-chairs

Bo Gu, Bos Photonics (United States)

Andreas Tünnermann, Fraunhofer-Institut für Angewandte Optik und Feinmechanik (Germany) and Friedrich-Schiller-Universität Jena (Germany)

Program Track Chair

Gregory J. Quarles, Optoelectronics Management Network (United States)

Conference Chairs

Abdul A. S. Awwal, Lawrence Livermore National Laboratory (United States)

Monya A. Lane, Lawrence Livermore National Laboratory (United States)

Conference Co-chairs

Mike Dunne, SLAC National Accelerator Laboratory (United States) Ruxin Li, Shanghai Institute of Optics and Fine Mechanics (China) John L. Collier, Rutherford Appleton Laboratory (United Kingdom) Kinioki Mima, Osaka University (Japan)

Conference Program Committee

Ghaleb M. Abdulla, Lawrence Livermore National Laboratory (United States)

Christopher P. J. Barty, Lawrence Livermore National Laboratory (United States)

Mark W. Bowers, Lawrence Livermore National Laboratory (United States)

Genevieve M. Chabassier, Commissariat à l'Énergie Atomique (France)

Gilles Chériaux, Laboratoire d'Optique Appliquée (France) 
Jean-Michel G. Di Nicola, Lawrence Livermore National Laboratory (United States)

Constantin L. Haefner, Lawrence Livermore National Laboratory

(United States)

John E. Heebner, Lawrence Livermore National Laboratory

(United States)

Laurent Hilsz, Commissariat à l'Énergie Atomique (France)

Tae Moon Jeong, Gwangju Institute of Science and Technology

(Korea, Republic of)

Brian E. Kruschwitz, University of Rochester (United States)

Richard R. Leach Jr., Lawrence Livermore National Laboratory

(United States)

Catherine Le Blanc, Laboratoire LULI, Ecole Polytechnique (France)

Bruno J. Le Garrec, ELI Beamlines (Czech Republic)

Zunqi Lin, Shanghai Institute of Optics and Fine Mechanics (China)

Noriaki Miyanaga, Hamamatsu Photonics K.K. (Japan)

Mark A. Newton, Lawrence Livermore National Laboratory (United States)

Takayoshi Norimatsu, Osaka University (Japan)

Shahida I. Rana, Lawrence Livermore National Laboratory

(United States)

John M. Soures, University of Rochester (United States)

Kazuo A. Tanaka, Osaka University (Japan)

Julien B. Xavier, Commissariat à l'Énergie Atomique (France)

Changhe Zhou, Shanghai Institute of Optics and Fine Mechanics (China)

Session Chairs

1 High Power Laser Facilities

Monya A. Lane, Lawrence Livermore National Laboratory (United States)

2 High Power Optical Materials

Abdul A. S. Awwal, Lawrence Livermore National Laboratory

(United States)

3 Simulations and Experiments

Jean-Michel G. Di Nicola, Lawrence Livermore National Laboratory (United States)

4 Laser Subsystems/Diagnostics

Mark W. Bowers, Lawrence Livermore National Laboratory

(United States) 


\title{
Introduction
}

This is the third biennial conference on High Power Lasers for Fusion Research. Our objective has been to showcase the continual progress made in high power laser development, which is associated with the goal of demonstrating inertial confinement fusion in the laboratory. In different parts of the world, scientists are making significant progress in constructing these large laser facilities (paper 1). In other parts, new laser subsystems are being added to develop novel diagnostics for visualizing and understanding the nature of the experimental reaction and possible methods of tuning (paper 16).

This year, the conference attracted twenty-six contributed and invited presentations in the areas of status of High Power Lasers Facilities around the world (with presentations from LLNL, LEA, ELI and RAL), High Power Optical Materials, Simulations and Experiments, and Laser Subsystems/Diagnostics. We were encouraged by the large number of attendees and the questions they asked every speaker. We attracted papers from many different countries around the globe including United States, France, United Kingdom, Czech Republic, Germany, Russian Federation and China. There was also interest from the industry in presenting results of lasers and components which may find future application in high power lasers. We did not see any gaps in papers from this conference.

\author{
Abdul A. S. Awwal \\ Monya A. Lane
}


Proc. of SPIE Vol. $9345934501-10$

Downloaded From: https://www.spiedigitallibrary.org/conference-proceedings-of-spie on 26 Apr 2023 Terms of Use: https://www.spiedigitallibrary.org/terms-of-use 